Boise State University

ScholarWorks

Criminal Justice Faculty Publications and

Presentations

Department of Criminal Justice

11-1-2008

\title{
The Effect of Blakely v. Washington on Upward Departures in a Sentencing Guideline State
}

Brian Iannacchione

Boise State University

Jeremy Ball

Boise State University 


\title{
The Effect of Blakely v. Washington on Upward Departures in a Sentencing Guideline State
}

\author{
Brian Iannacchione, MA \\ Department of Criminal Justice \\ Boise State University \\ $\&$ \\ Jeremy D. Ball, JD, $\mathbf{P h D}^{1}$ \\ Department of Criminal Justice \\ Boise State University
}

One of the problems facing the criminal justice system is unwarranted disparity as a result of unbridled discretion. Although disparity, by itself, does not necessarily indicate a problem in the criminal justice system, disparity unwarranted does present a problem. Disparity becomes unwarranted when, controlling for legal factors, extralegal factors such as race/ethnicity, gender, and age influence court processing decisions. The greater the discretion one possesses, the higher the likelihood of unwarranted disparity in one's decisions (Albonetti, 1991; Meeker, Jesilow, \& Aranda, 1992; Bushway \& Piehl, 2001). Within the criminal court system, judicial discretion in sentencing has received the most scrutiny.

More than thirty years ago, there was a call to reform the indeterminate sentencing schemes used in the 1970s (Spohn, 2002). One of the suggestions was to implement a sentencing guideline system where judges' sentencing decisions would be streamlined by funneling sentences through a matrix system, cross-sectioning offense severity and prior record level. There were many goals to the sentencing guidelines. One of those goals was to reduce unwarranted sentencing disparity brought on by unfettered discretion judges had in indeterminate sentencing (Hofer, Loeffler, Blackwell, \& Valentino, 2004). Certainty of punishment, therefore, was more important than the autonomy of judges, given this new reform. The sentence guideline system attempted to increase the transparency and rationality of punishment (Hofer et al, 2004).

One of the purposes of sentencing guidelines was to reduce discretion - and, thereby, unwarranted disparity (see Spohn, 2000; Tonry, 1996). One area of discretion that judges retained was in the area of departure sentencing. In other words, judges could, given particular circumstances, depart from the sentence guideline range. An upward

\footnotetext{
${ }^{1}$ Please address any comments and questions to Jeremy Ball at the following ADDRESS: Department of Criminal Justice, Boise State University, 1910 University Drive, Boise, ID 83725-1955 PHONE: (208) 426-3769 FAX: (208) 426-4371 E-MAIL: jeremyball @ boisestate.edu
} 
departure - or, aggravated sentence - can occur if the judge deemed it to be appropriate to raise the sentence above the guideline range maximum. A downward departure - or, mitigated sentence - can occur if the judge deemed it to be appropriate to lower the sentence below the guideline range maximum. Until recently, the decision of an upward departure was left in the hands of the judge.

Recently, the practice of raising the sentence above the guideline range maximum was put into question by the United States Supreme Court in Blakely v. Washington (2004). The United States Supreme Court ruled that, while upward departures are still allowed, a jury must now decide the facts upon which an upward departure is made rather than relying on the sole discretional authority of the judge. Prior to Blakely, the judge, under the guise of judicial discretion, would consider certain factors during the sentencing phase. These facts may or may not have been substantiated by the rigors of the guilt phase of the trial. The Court ruled that this practice violated the defendant's right to a jury trial and required that these facts be proven by the same standard as any other facts during the guilt phase - that is, beyond a reasonable doubt. This ruling, therefore, limited the little discretional authority the judge might have had (see McVoy, 2005; Wool \& Stemen, 2004). "If state and federal sentencing guidelines represented a revolution in sentencing theory and practice, then Blakely, it is feared, will spark a counter-revolution" (Frase, 2007, 404).

Given that judicial discretion and disparate decisions are linked in sentencing reforms (see Spohn, 2000) and given that the Blakely decision further limited judicial discretion (McVoy, 2005; Wool \& Stemen, 2004), research is needed to address discretion and the potential for a decrease in disparities in aggravated sentencing decisions after the Blakely decision compared to before Blakely. Although there has been a fair amount of empirical research on unwarranted disparities in aggravated sentencing decisions and a fair amount of legal commentaries on the Blakely decision, to date, there has been no empirical, systematic study of the connection of the two - that is, the connection of the Blakely ruling and disparities in aggravated sentencing. This study serves as an explorative first step in examining upward departures and the potential disparate pitfalls that might exist before Blakely but not after Blakely.

\section{$\underline{\text { Research on Aggravated Sentencing }}$}

Although there has been no empirical research on the effect of Blakely on departure decisions, there has been research on departure decisions prior to this ruling. Since the Supreme Court ruled on aggravated sentences, the review of literature only addresses upward departures. A few interesting findings on downward departure decisions are footnoted. Legal factors have a major role in whether a judge aggravates the sentence above the sentence guideline range maximum. Engen, Gainey, Crutchfield, and Weis (2003) studied aggravated sentences in the state of Washington where they found that legal variables - offense severity and prior record level - increased the odds of an upward departure. ${ }^{2}$ In other words, defendants with a more serious offense and/or prior record are more likely to receive an aggravated sentence.

Johnson (2003) examined departure sentencing in Pennsylvania and found that legal variables have a statistically significant effect on upward departures albeit in a direction that was unexpected. They found that an increase in offense severity or an increase in the defendant's prior record led to a decrease in the odds of an upward departure (Johnson, 2003). Examining sentencing under the Pennsylvania sentencing guidelines, Kramer and Ulmer (2002) suggested that courtroom actors may not agree with the harshness of the penalty or view these defendants as less blameworthy and, therefore, adjust their decision (charging, plea bargaining or sentencing) to coincide with their beliefs.

Some research has identified mode of conviction as an important factor influencing aggravated sentencing. Engen and his colleagues (2003) found that those who were convicted at trial had a greater chance of receiving an upward departure than those who pled guilty. In studying these same effects in Pennsylvania, Kramer and Ulmer (1996) found that defendants convicted at trial receive, on average, a larger magnitude of aggravated sentence than either those convicted in a bench trial or those who pled guilty.

\footnotetext{
${ }^{2}$ However, they found that the odds of a mitigated sentence decreased given a more serious offense and/or more serious prior record.
} 
Research has also suggested that other extralegal factors influence the decision to aggravate sentences. Engen and his colleagues (2003) concluded that race and/or ethnicity had significant yet mixed effects on upward departures. The odds that Hispanic defendants received an upward departure was $68 \%$ higher than the odds for white defendants, whereas the odds that black defendants received an upward departure was $35 \%$ lower than the odds for white defendants (Engen et al., 2003). Unlike Engen et al. (2003), however, Johnson (2003) found that race positively affected upward departures. Johnson (2003) found that black defendants were more likely to receive an upward departure whereas Engen et al.(2003) found that black defendants were less likely to receive an upward departure. Johnson (2003) suggested that judges perceive racial minorities as more of a threat and less likely to be rehabilitated than white defendants.

Prior research also studied whether gender is related to the sentencing departure decision. Engen and his colleagues (2003) found that gender had no statistically significant effect on the likelihood of upward departure sentencing. ${ }^{3}$ On the other hand, Johnson (2003) found that male defendants were statistically more likely to receive upward departures than female defendants, linking to the judicial perception of blameworthiness and dangerousness.

Research has also outlined the relationship of age and departure sentencing. Engen and his colleagues (2003) found a statistically significant relationship between age and upward departures, finding that older defendants were more likely to receive upward departures than younger defendants. Johnson (2003) found a dissimilar finding for upward departures in that older defendants were less likely to receive an upward departure than younger defendants. He suggested that younger defendants likely carry a stigma that leads judges to be more punitive (Johnson, 2003).

The research indicates that there is a relationship between legal variables - namely, offense severity and prior record level - and the decision to depart from the sentencing guideline range. There is some - albeit mixed - evidence that extralegal factors have an effect on the aggravated sentence decision. The question, though, is whether the recent Supreme Court ruling in Blakely v. Washington (2004) impacted upward departure decisions. Given the greater restraint on judicial discretion and the formalized rules on sentencing in Blakely v. Washington (2004), the impact of these extralegal factors on upward departures should be minimized after Blakely compared to before Blakely

\section{The Sentencing Guidelines and the United States Supreme Court}

Three landmark United States Supreme Court cases set the stage for a study of upward departure sentencing. In 1989, the United States Supreme Court, in Mistretta v. United States (1989), ruled that sentencing guidelines were constitutional and did not violate the separation of powers clause in the United States Constitution. The Supreme Court did not address the constitutionality of sentencing guidelines or decisions within sentencing guidelines states ${ }^{4}$ until their landmark ruling in Blakely v. Washington (2004).

\section{Apprendi v. New Jersey 530 U.S. $466(2000)$}

Before outlining the ruling in Blakely, it is imperative to summarize the Supreme Court ruling in Apprendi v. New Jersey which set the precedent for Blakely. Charles Apprendi fired shots into the home of a black family. He was charged with and pled guilty to second-degree possession of a firearm for unlawful purpose. This offense carried with it a five to ten year prison sentence. Originally, the state did not charge Apprendi with a hate crime, which would allow for an enhanced sentence. After Apprendi pled guilty, the prosecutor filed a motion to enhance the sentence because of the racial motivation of the case. The judge found, by preponderance of the evidence, that the crime was racially motivated and sentenced Apprendi to twelve years in prison, two years over the statutory maximum of the original charges.

Apprendi appealed, suggesting that any fact presented to the court which increases the statutory maximum for which a defendant was already charged and convicted violated his right to a jury trial granted to him under the Sixth Amendment. The Supreme Court agreed and ruled that the United States Constitution required that any fact that may

\footnotetext{
${ }^{3}$ They did find, though, that gender has a statistically significant effect on downward departure sentencing, finding that the odds of receiving a downward departure is $46 \%$ greater for female defendants than for male defendants.

${ }^{4}$ The Supreme Court also addressed the federal sentencing guidelines in United States v. Booker and United States v. Fanfan, 543 U.S. 220 (2005). However, the scope of this study is limited to state sentencing guideline systems.
} 
increase the penalty of a crime beyond the maximum sentence already set forth by statute must be both submitted to a jury and proved beyond a reasonable doubt. The only exception to this rule is evidence of prior convictions. The ruling in Apprendi set the stage for the decision in Blakely.

\section{Blakely v. Washington 542 U.S. 296 (2004)}

Unlike Apprendi, which focused on sentencing above the statutory maximum, Blakely focused on sentencing above the guideline maximum. Ralph Blakely, Jr. was married to his wife Yolanda for 25 years. Complications arose, which led to Yolanda filing for divorce. In 1998, Blakely kidnapped Yolanda from their home in the state of Washington, bound her with duct tape, and forced her into a wooden box in his truck. Blakely took Yolanda to a friend's house in Montana, where he was arrested.

Blakely eventually pled guilty to second-degree kidnapping involving both domestic violence and the use of a firearm. These charges carried a maximum sentence of 53 months according to the sentencing guidelines in the state of Washington. The judge, however, after hearing Yolanda's testimony and the cruelty that was involved, imposed an aggravated sentence of 90 months. Blakely appealed, arguing that this sentence deprived him of his constitutional right to have a jury decide all legally relevant factors that may affect his sentence. The Court agreed, applying the precedent set forth in Apprendi v. New Jersey (2000). The facts were neither admitted by the defendant nor submitted to the jury, leading the Court to rule that his Sixth Amendment rights had been violated. The judge could not impose a sentence above the prescribed sentence guideline range maximum in violation of his Sixth Amendment rights.

Blakely v. Washington (2004), thus, followed in the footsteps of Apprendi v. New Jersey (2000) by upholding the Sixth Amendment rights of the defendant. Judges were no longer to depart above the guideline range maximum unless a jury hears and admits all the sentencing factors of the case. The only exception to this is when a judge considers prior felony convictions.

\section{The Impact of Blakely v. Washington}

The impact of Blakely cannot be taken for granted. Berman (2005) concluded that "Blakely may be the most consequential and important criminal justice decision not just in recent terms, not just on the Rehnquist Court, but perhaps in the history of the Supreme Court" (p. 41). Although the use of aggravated sentencing is not typical, its immediate effects were widespread. Within weeks, state courts and lower federal courts were already ruling that the Federal Sentencing Guidelines were unconstitutional based on the precedent set in Blakely and Apprendi (Berman, 2005).

Bowman (2004) suggested that "[Blakely] really is unprecedented in effect. No Supreme Court opinion in living memory, perhaps no opinion in American history, has caused near-paralysis of either state or federal criminal justice systems by placing the outcome of every case in doubt" (p. 252). Some have suggested, therefore, that presumptive sentencing guidelines should simply be voluntary instead (Frase, 2007). One of the main problems with Blakely is the directional bias it now imposes on the right to jury trial (Bowman, 2004). Juries are now required to find facts that increase a sentence above the guideline range maximum, yet the Court in Blakely does no give the jury the right to determine facts that either set a defendants' minimum sentence or mitigate a defendants' presumptive sentence.

\section{CURRENT STUDY}

The purpose of the current study is to explore the potential effect of the Supreme Court's ruling in Blakely v. Washington on upward departures from the sentencing guidelines. Prior research suggested both legal and extralegal factors may play a role when a judge decides to depart from the guidelines. One of the purposes of the sentencing guidelines was to reduce discretion and increase certainty of punishment (Spohn, 2000). Given that judges, prior to 
Blakely, had discretional authority to aggravate sentences above the sentencing guideline range maximum and that discretion may lead to reliance on extralegal factors, this study examines upward departures both before and after the Blakely decision to reveal any potential reduction in unwarranted disparity in upward departure decisions in the state of Washington. ${ }^{5}$

\section{Hypotheses}

Since judicial discretion is further limited given the ruling in Blakely, it is hypothesized that aggravated sentences are less common after the decision in Blakely compared to before this decision. Another set of hypotheses is related to prior research that suggested that judges take numerous legal and extralegal variables into account in their sentencing decisions. The focal concerns theory (see Steffensmeier et al., 1998) suggests that judges view particular defendants to be more blameworthy and/or more dangerous than other defendants. It is the contention, given the ruling in Blakely, that judges are more likely to impose an upward departure for minority defendants, for younger defendants, and for male defendants prior to Blakely but not after Blakely.

\section{METHODOLOGY}

The current study examines sentencing data collected from the state of Washington to study whether or not the decision of Blakely $v$. Washington (2004) affects the likelihood of upward departures. The sample for this study is drawn from all sentencing decisions in felony cases resulting in a guilty decision in the state of Washington. ${ }^{6}$ A pretest/post-test research design is employed, examining cases decided within twenty-seven months ${ }^{7}$ before Blakely (pre-Blakely hereafter) and twenty-seven months after Blakely (post-Blakely hereafter). Blakely v. Washington was decided on June 24, 2004; therefore, this study encompasses cases from March 2002 to May 2004 representing preBlakely and cases from July 2004 until October 2006 representing post-Blakely.

Since the population of cases includes mostly non-aggravated sentences (over 98\%), a disproportionate stratified sample was used. A disproportionate stratified sample takes "a larger than proportionate number of certain groups to assure the appearance of a sufficient number of cases for comparative purposes of a group that is small in the population. (Hagan, 2005, p. 136; see also Champion, 2006; Maxfield \& Babbie, 2008). "[I]f only a small number of people in a population exhibit some attribute or characteristic of interest, then a large sample must be drawn to produce adequate numbers of elements that exhibit the uncommon condition." (Maxfield \& Babbie, 2008, p. 229). Several studies have utilized this approach comparing degrees earned by inmates while incarcerated (Batiuk, Lahm, Mckeever, Wilcox, \& Wilcox, 2005), attitudes towards juvenile death penalty among different racial/ethnic groups (Vogel \& Vogel, 2003), executed sentences before and after the imposition of the sentencing guidelines in Minnesota (Miethe, 1987), juvenile referrals among different racial/ethnic categories (Leiber, 1993), and punishment severity of illegal aliens and non-illegal aliens (McShane, 1987)

The current study uses a disproportionate stratified sampling procedure to produce a higher proportion of cases resulting in an aggravated sentence compared to their representation in the population of cases. For the overall sample of cases in the 52-month period surrounding the Blakely decision, the population of cases resulting in an aggravated sentence (or, upward departure) is included and an equal number of randomly selected cases resulting in a non-aggravated sentence are included in the analyses. ${ }^{8}$ The purpose of using this sampling procedure is two-fold. First, the sampling procedure allows for heterogeneity in the variable of interest. With only $1.9 \%$ of the cases resulting in an aggravated sentence in the overall population, the dependent variable is homogenous and appears to

\footnotetext{
${ }^{5}$ Since the current study examines data in the state of Washington, it is possible the findings in the current study might be applicable only to Washington and not other sentencing guideline states. The explorative nature of this study should lend support to other relevant examinations in other sentencing guideline states. This limitation is further addressed in the discussion section.

${ }^{6}$ The limited data were provided by the Sentencing Guidelines Commission of Washington.

${ }^{7}$ The initial proposal for this project was presented in October 2006 which necessitated a 27 month pre- and postperiod.

${ }^{8}$ The results are slightly different comparing the sampling structure used in this study to the overall population of cases within the given time frame.
} 
be more like a constant than a variable. Second, using the entire population of cases arguably results in masked findings. The sheer number of cases resulting in a non-aggravated sentence overwhelms potentially important influences on upward departures before and after Blakely.

\section{Variables}

The dependent variable for this study is whether or not a case received an aggravated sentence - identified as an "exceptional sentence" in the state of Washington. Upward departures (or aggravated sentences) were coded as one and all other sentences - within or below the sentence guideline range - were coded as zero.

Several legal and/or extralegal variables are included to examine potential effects on the decision to depart above the sentencing guideline range maximum. Due to the explorative purpose of this research and the secondary nature of the data, other relevant factors - such as type of current offense - were not made available. This is a limitation of this current study, but it is believed that some important first steps can be taken in exploring this field of study. The legal variables in this study are the severity of the current offense and prior record level. The severity of the current offense is measured by the offense score (range $=0-15$ ) as determined by the sentencing guidelines in the state of Washington. A higher offense severity score indicates a more severe current offense. The prior record level is measured by the prior record score which is a ranked value of the offender's prior convictions (range $=0-9)$ rather than a count of prior convictions. This prior record score is determined by a calculus provided by the Sentencing Commission in the state of Washington. This calculus ${ }^{9}$ consists of four general variables: adult history, juvenile history, other current offenses, and the status of the offender. The number of convictions - usually felony - or factors at each stage is multiplied (or weighted) by the severity of those convictions (e.g. serious violent, other violent, non-violent) or factors. The total number for each of these categories is then summed to obtain the prior record score - called an "offender score." Calculations can be oriented differently based on the type of current offense conviction. A higher prior record score indicates a higher prior record level.

The current study also includes several extralegal variables that may affect a judge's decision to increase the sentence above the sentencing guideline range maximum. The extralegal variables that are included in this study are race/ethnicity, age, gender, and mode of conviction. Race/ethnicity is coded as a dummy variable: white, black, Hispanic, and other. In the multivariate analysis, "white" is the reference category against which the other categories are compared. Mode of conviction is a dichotomous variable measuring whether the defendant was found guilty in a bench/jury trial or pled guilty.

Along with basic descriptive analyses, three logistic regression analyses are run: baseline model with a pre-post variable included, pre-Blakely model, and post-Blakely model. This analysis allows for comparisons of the effects of the extralegal variables on the decision to impose an upward departure before and after Blakely. Additionally, a comparison of significant unstandardized coefficients is conducted by running a differences in slopes test for independent samples (see Paternoster, Brame, Mazerolle, \& Piquero, 1998). This analysis allows for a comparison between the significant findings in the pre-Blakely period and the post-Blakely period to test whether one significant factor has a stronger effect on the dependent variable for one sample compared to the other sample. This test, if successful, might indicate that the effect of post-Blakely factors may have a weaker hold on upward departures compared to the same pre-Blakely factors despite there being significance in both samples

Since the data are limited to what was provided, the strength of the findings is somewhat limited. However, to date, no empirical analysis has explored the effect of Blakely on sentence guideline departures using a pre-test and posttest design. Therefore, this study will shed some light on an area of study not already explored.

\footnotetext{
${ }^{9}$ Please see the Washington State Sentencing Guidelines Commission website for further details (http://www.sgc.wa.gov/PUBS/Interactive/formlinks.asp\#d accessed April 10, 2008).
} 


\section{FINDINGS}

The overall sample from which this study further partitioned consists of 116,274 cases and includes approximately $80 \%$ male defendants. The majority of defendants are white (77\%), while blacks made up $14 \%$ and Hispanics $4 \%$ of the sample. The average age of the individuals in this overall sample is approximately 34 years old. The vast majority of cases resulted in a guilty plea (96\%) and approximately $2 \%$ resulted in an aggravated sentence - or, upward departure.

The partitioned baseline sample is similar to the larger sample in every way except the percentage of aggravated sentences. More specifically, the baseline sample includes 50\% cases resulting in an aggravated sentence and 50\% cases resulting in a non-aggravated sentence. See Table 1 for a summary of the descriptive statistics for the baseline sample. The vast majority of defendants are male $(82.8 \%)$ and white $(77.3 \%)$ with $13.5 \%$ black and $4.5 \%$ Hispanic. The average age in the baseline sample is approximately 35 years old and most cases resulted in a guilty plea (95\%).

Insert Table 1 here

Due to the pre-test, post-test design of the study, it is important to address important differences in the makeup of cases adjudicated in Washington before and after the Supreme Court ruling in Blakely v. Washington. Table 2 highlights the descriptive statistics of both the pre- and post-Blakely samples. The pre-Blakely sample includes 2,709 cases. Over half of the pre-Blakely sample resulted in an upward departure. Similar to the baseline and overall sample, $77.3 \%$ of the defendants are white, $13.4 \%$ are black, and $4.6 \%$ are Hispanic. The pre-Blakely sample is mostly male (83.4\%), similar to the percentages found in the baseline and overall samples. The average age of this sample is approximately 36 years old, and the vast majority of the pre-Blakely sample pled guilty (93.6\%).

\section{Insert Table 2 here}

In the post-Blakely sample, there is a decrease in the percentage of cases resulting in an upward departure (41.4\%). This decrease might be an effect of the Supreme Court decision in Blakely v. Washington. In the post-Blakely sample most of the defendants are male $(81.9 \%)$ and white $(77.3 \%)$ with black defendants making up $13.6 \%$ and Hispanic defendants making up $4.2 \%$ of the sample. The average age is only slightly younger - approximately 34 years old. There are slightly more cases that resulted in a guilty plea (97.5\%) compared to the pre-Blakely sample which may indicate a trend that the prosecutor has a bigger role in plea bargaining cases that would likely garner an upward departure.

\section{Multivariate Analyses}

Logistic regression is used to examine the effects of offender characteristics on upward departures, controlling for legally relevant factors. Logistic regression is run to account for the dichotomous nature of the dependent variable (Menard, 2002). These analyses are run for the baseline sample as well as for the pre- and post-Blakely samples. The current study also conducts a differences in slopes test between the pre-Blakely and post-Blakely samples to make an inferred conclusion of the impact of the Blakely decision on the determinants of upward departure decision-making. If the differences in slopes test is found to be statistically significant, then it can be suggested that a variable has a stronger or weaker influence in one sample compared to the other sample. Given that the major difference between the two samples is whether the sample was taken before or after the Blakely decision, it can be suggested that the influence is uniquely tied to the Supreme Court ruling in Blakely. However, the power of this conclusion is somewhat limited due to the limited number of factors taken into consideration.

\section{Baseline Model}

The model for the baseline sample indicates that all legal and some of the extralegal factors are found to be statistically significant $(\mathrm{p}<.05)$. The findings from the baseline regression analyses summarized in Table 3 indicate that there is a statistically significant $(\mathrm{p}<.05)$ decrease in the use of upward departures. In fact, the odds of a case receiving an upward departure after the Blakely decision is $69 \%$ less than the odds of receiving an upward departure before the Blakely decision. Table 3 shows that offense severity and prior record level have a positively significant impact on the decision to aggravate the sentence. As expected, when the offense severity and/or prior record level increase, the likelihood of an upward departure increases. Most of the extralegal variables - gender, age, and mode 
of conviction - are also found to have a positively significant impact on upward departures. For the most part, race and/or ethnicity were found not to have an effect on the decision to aggravate the sentence $(\mathrm{p}>.05)$. The largest substantive effect of a particular variable on the aggravated sentence decision is gender. Male defendants are almost twice as likely to receive an upward departure as female defendants.

Insert Table 3 here

\section{$\underline{\text { Pre-Blakely Model }}$}

Similar to the baseline model, the pre-Blakely model only has a $4.7 \%$ reduction in error $\left(\right.$ Nagelkerke $\left.\mathrm{R}^{2}=0.047\right)$ which indicates that important factors are not considered in model construction. This problem, though, is typical of explorative research and secondary data analysis. The statistically significant factors $(\mathrm{p}<.05)$ in this sample are prior record, age, and gender. Male defendants are over twice as likely to receive an upward departure as female defendants (odds ratio $=2.038$ ). The substantive effects of prior record and age are minimal. Unlike the baseline model, though, offense severity and "other race/ethnicity" is not a statistically significant effect $(\mathrm{p}>.05)$.

\section{Post-Blakely Model}

The findings for the post-Blakely sample are also included in Table 3. The statistically significant predictors (p $<$ $.05)$ of the upward departure decision after the Supreme Court's decision in Blakely v. Washington in 2004 are prior record, age, gender, and whether the defendant's race/ethnicity was characterized as "other" or not. The most substantive of these effects is whether the defendant's race/ethnicity category was "other" or not. Defendants who are in the "other" racial/ethnic category are approximately two times less likely to receive an upward departure (odds ratio $=0.517$ ) than white defendants. ${ }^{10}$ Male defendants are over $1 \frac{1 / 2}{2}$ times more likely to receive an aggravated sentence above the sentence guideline range maximum than female defendants (odds ratio $=1.774$ ). Although statistically significant, the prior record level and age of the defendant yields little substantive influence on predicting whether the particular defendant receives an upward departure or not.

Since a few of the extralegal variables are statistically significant in both the pre-Blakely sample and the postBlakely sample, the differences in slopes test can be used to compare the unstandardized effects of the same variable between independent samples (see Paternoster et al., 1998). This test can further articulate whether (and which) significant factors have more influence in one sample compared to another sample. The samples, in this instance, are cases before Blakely and cases after Blakely. These results are summarized in Table 4.

Insert Table 4 about here

The results of this analysis indicate that the test did not provide a statically significant difference in the influence of these variables between the pre-Blakely and post-Blakely samples. However, it should be noted that the $\mathrm{z}$ score for prior record is positive and the $\mathrm{z}$ scores for each of the included extralegal variables are negative. A positive $\mathrm{z}$ score in this analysis indicates that the variable has stronger influence in the post-Blakely sample than in the pre-Blakely sample, whereas a negative $\mathrm{z}$ score indicates that the variable has a weaker influence in the post-Blakely sample than in the pre-Blakely sample. Therefore, the legal variable included in this test is "approaching" stronger influence and the extralegal variables are "approaching" weaker influence after Blakely compared to before Blakely. It should be cautioned, though, that the $\mathrm{z}$ scores were still found not to be statistically significant. Therefore, the formal conclusion is that there is no difference of influence between the independent samples. From a theoretical standpoint, though, the direction of the $\mathrm{z}$ score is an important one to note.

\section{DISCUSSION}

The Supreme Court in Blakely v. Washington limited judicial discretion - even further than the sentencing guidelines themselves. One of the purposes of sentencing guidelines was to limit discretion and reduce unwarranted disparity. Given this ruling, it was suggested that the likelihood of upward departure sentencing - an area of judicial discretion still remaining until Blakely - should result in very little, if any, unwarranted disparate decision-making.

${ }^{10}$ The calculated odds ratio can be transformed by dividing the calculated odds ratio into 1 to obtain an inverse ratio of 1.934. The greater the distance of the value of odds ratio below 1 yields a greater "negative" likelihood. 
The hypotheses of this research, therefore, posited that the extralegal variables - race/ethnicity, gender, and agewould only have significant effects before Blakely but not after Blakely. If statistically significant relationships still exist after Blakely, it is suggested that the influence of extralegal factors should be weaker than before Blakely.

Although the majority of cases in this study did not result in an upward departure, it was found that the odds of an upward departure was greater before Blakely than after Blakely. There was also some indication that extralegal factors influence the judge's decision to aggravate the sentence above the sentence guideline range maximum. Although prior record score was found to be statistically significant in all models (i.e., baseline, pre-Blakely, and post-Blakely), other factors such as age and gender were also found to be statistically significant. Substantively, other than the post-Blakely model, gender had the most substantive meaningful effect. In the post-Blakely model, race/ethnicity (i.e., "other") had the most substantively meaningful effect.

The hypotheses regarding the influence of extralegal factors on aggravated sentencing were not supported in these findings. In other words, it was suggested that race/ethnicity, gender, age, and mode of conviction would not have an effect on the decision to aggravate the sentence above the sentence guideline range maximum after the Supreme Court's ruling in Blakely $v$. Washington. The results indicate that age and gender had an effect on the upward departure decision before and after the Blakely ruling.

An area of research that does not garner the scholarly attention is in the area of prosecutorial discretion. Given that the prosecutor holds great discretional authority in the American criminal court system and given that there is renewed restrictions on judicial discretional authority with the ruling in Blakely, the finding of disparate sentencing may be a somewhat muted result of disparate discretionary decision-making by the prosecutor. The discretional authority may have simply been displaced from the judge to the prosecutor. A prosecutor can have significant influence on sentencing decisions through charging and plea bargaining cases.

\section{Limitations}

This study's findings should be taken as simply explorative. One of the limitations of this study is a product of using secondary data; that is, there is an absence of relevant variables in the models. A key factor in a judge's determination of aggravating a sentence or not is the type and/or strength of evidence brought forward. Since the ruling in Blakely hinges on the evidence upon which the aggravated sentence is relied, it would be important to include these factors when constructing the proposed models. The type of crime committed by the offender would be important to include since racial/ethnic differences are likely contextualized by crime type. Another factor not considered is whether a weapon was used or not during the commission of the crime. Type of attorney was also not included. The type of attorney - public or private - has also been found to play a role in sentencing decisions, with defendants assigned to public defenders more likely to receive more severe sentences than those with private attorneys (see Chiricos \& Bales, 1991; Spohn, 2002). Another key variable missing from this dataset is the race/ethnicity of the judge. Steffensmeier and Britt (2001) suggested that, while there is considerable overlap in the sentences imposed by all judges, black judges are more likely to incarcerate defendants and their sentencing decisions are more punitive in nature.

Another limitation is the lack of qualitative information about why judges aggravated sentences for particular defendants but not for others. Including this information might give more insight about why judges impose aggravated sentences - or, upward departures. Starting dialogues with judges from Washington may glean more information on exactly what is taken into account when they decide to sentence an offender above that suggested by the sentence guidelines. It would also be important to know why some extralegal variables - gender and age - still have an effect after Blakely. Due to the time constraints of this project, though, qualitative data were not collected.

A final limitation is that data were only analyzed from one state. While the findings from this study can be generalized to other states with sentencing guidelines in a general way, the findings from this study cannot be generalized in a specific way. In other words, although sentencing guidelines are similar, there are enough differences to analyze data from each state to mete out important differences between states. For example, Washington's sentencing guidelines are more narrowly defined than other states' sentencing guidelines by already disallowing upward departures based on facts to prove an offense that was not formally charged (Frase, 2007). It is 
possible, therefore, that important potential findings were masked using such a restrictive sentencing guideline state. It is also difficult to apply this research to non-sentence guideline states due to the differences in sentencing philosophies between guideline states and non-guideline states.

In conclusion, Berman (2005) found a silver lining in the Blakely decision. Blakely caused major confusion in the conceptualization of sentencing; however, the problem is that the sentencing reform movement was underdeveloped in both theory and practice in the first place. The Blakely ruling offers a chance, in Berman's (2005) opinion, to reconceptualize the modern sentencing reforms. He suggested that the sentencing revolution rejected rehabilitative theory and had lax administrative procedures for the application of a new sentencing structure, both of which have not been addressed by policymakers, courts, or academics (Berman, 2005). Regardless of one's thoughts on Blakely, he argued that it should be praised for stimulating a national dialogue on sentencing policy, law procedures, and practices (Berman, 2005). With the swelling of both state and federal prison populations, new sentencing reforms are in order, and the dialogue started by Blakely may lead to drastic changes - especially if it is successful in further limiting judicial discretion and eliminating unwarranted disparity once and for all. Frase (2007) suggested that one of these drastic changes might be creating voluntary sentencing guideline systems that were once presumptive.

The Supreme Court's ruling in Blakely v. Washington further restricted judicial discretion by limiting the ability to depart above the predetermined sentencing guideline range. After this ruling, a judge must garner a factual determination of the facts upon which s/he can grant an upward departure. This study finds, in a formal way, that even though judicial discretion is further limited, disparities still exist in judges' aggravated sentencing decisions. This study is explorative; more extensive research should continue to analyze the potential effects of the Supreme Court's ruling in Blakely v. Washington in sentencing guideline states on upward departures.

\section{REFERENCES}

Batiuk, M. E., Lahm, K.F., Mckeever, M., Wilcox, N., \& Wilcox, P. (2005). Disentangling the effects of correctional education: Are current policies misguided? An event history analysis. Criminal justice, 5, 5574.

Albonetti, C. (1991). An integration of theories to explain judicial discretion. Social Problems, 38, $247-266$.

Berman, D.A. (2005). Reconceptualizing sentencing. University of Chicago Legal Forum, 1-53.

Bowman, F.O. (2004). Train wreck? Or can the federal sentencing system be saved? A plea for rapid reversal of Blakely v. Washington. American Criminal Law Review, 41, 217-265.

Bushway, S., \& Piehl, A.M. (2001). Judging judicial discretion: Legal factors and racial discrimination in sentencing. Law \& Society Review, 35, 733-764

Champion, D. J. (2006). Research Methods for Criminal Justice and Criminology ( $3^{\text {rd }}$ Ed.). Upper Saddle River, NJ: Pearson.

Engen, R.L., Gainey, R.R., Crutchfield, R.D., \&. Weis, J.G. (2003). Discretion and disparity under Sentencing guidelines: The role of departures and structured sentencingalternatives. Criminology, 41(1), 99-130.

Everett, R.S., \& Nienstedt, B.C. (1999). Race, remorse, and sentence reduction: Is saying you're sorry enough? Justice Quarterly, 14(1), 99-122.

Everett, R.S., \& Wojtkiewicz R.A. (2002). Difference, disparity, and race/ethnic bias in federal sentencing. Journal of Quantitative Criminology, 18, 189-211.

Frase, R. S. (2007). The Apprendi-Blakely cases: Sentencing reform counter-revolution? Criminology and Public Policy, 6, 403-432.

Hagan, F. E. (2005). Essentials of Research Methods in Criminal Justice and Criminology. Boston: Pearson. 
Hofer, P.J., Loeffler, C., Blackwell, K., \& Valentino, P. (2004). Fifteen years of guidelines sentencing: An assessment of how well the federal criminal justice system is achieving the goals of sentencing reform. United States Sentencing Commission, 1-145.

Johnson, B.D. (2003). Racial and ethnic disparities in sentencing departures across modes of conviction. Criminology, 41, 449-489.

Kramer, J.H., \& Ulmer J.T. (2002). Downward departures for serious violent offenders: Local court corrections to Pennsylvania's sentencing guidelines. Criminology, 40, 897-932.

Kramer, J. H., \& Ulmer, J. T. (1996). Sentencing disparity and departures from guidelines. Justice Quarterly, 13, 81-105.

Leiber, M. J. (1993). The disproportionate overrepresentation of minority youth in secure facilities: A survey of decision makers and delinquents. The Office of Criminal and Juvenile Justice Planning. (technical report)

Maxfield, M. G., \& Babbie, E. (2008). Research Methods for Criminal Justice and Criminology (5 ${ }^{\text {th }}$ Ed.). Thomson.

McCoy, K. M. (2005). 'What I have feared most has now come to pass': Blakely, Booker, and the future of sentencing, Notre Dame Law Review, 80, 1613-1614.

McShane, M. D. (1987). Immigration processing and the alien inmate: Constructing a conflict perspective. Journal of Crime and Justice, 10, 171-194.

Meeker, J.W. Jesilow, P., \& Aranda J. (1992). Bias in sentencing: A preliminary analysis of community service sentences. Behavioral Sciences and the Law, 10, 197-206.

Menard, S. (2002). Applied Logistic Regression Analysis. Thousand Oaks, CA: Sage.

Miethe, T. D. (1987). Charging and plea bargaining practices under determinate sentencing: An investigation of the hydraulic displacement of discretion. The Journal of Criminal Law and Criminology, 78, 155-176.

Paternoster, R., Brame, R., Mazerolle, P., \& Piquero, A. (1998). Using the correct statistical test for the equality of regression coefficients. Criminology, 36, 859-866.

Spohn, C. C. (2002). How Do Judges Decide? The Search for Fairness and Justice in Punishment. Thousand Oaks, CA: Sage.

Spohn, C. (2000). Thirty years of sentencing reform: The quest for a racially neutral sentencing process, National Institute of Justice: Criminal Justice 2000, Vol. 3, 427-502. Washington, DC: National Institute of Justice.

Steffensmeier, D., \& Britt, C.L (2001). Judges' race and judicial decision making: Do black judges sentence differently? Social Science Quarterly, 82, 749-764.

Steffensmeier, D. Kramer, J., \& Streifel C. (1993). Gender and imprisonment decisions. Criminology, 31, 411-443. Tonry, M. (1996). Sentencing Matters. New York: Oxford University Press.

Vogel, B. L. \& Vogel, R. E. (2003). The age of death: Appraising public opinion of juvenile capital punishment. Journal of Criminal Justice, 31, 169-183.

Wool, J., \& Stemen, D. (2004). Aggravated sentencing: Blakely v. Washington: Practical implications for state sentencing systems. Federal Sentencing Reporter, 17, 60-68. 


\section{CASES CITED}

Apprendi v. New Jersey 530 U.S. 466 (2000)

Blakely v. Washington 542 U.S. 296 (2004)

Mistretta v. United States 488 U.S. 361 (1989)

United States v. Booker, 543 U.S. 220 (2005) (consolidated with Fanfan)

United States v. Fanfan, 543 U.S. 220 (2005) (consolidated with Booker)

Table 1. Codes and Frequencies of Dependent and Independent Variables for the Baseline Sample

Variable

Dependent Variable

Upward Departures

Independent Variables

Extralegal Variables

Race/ethnicity

Gender

Age

Legal Variables

$0=$ white

3,180

1 = black

$554 \quad 13.5$

$2=$ Hispanic

$184 \quad 4.5$

$3=$ Other

$197 \quad 4.8$

$0=$ female

$715 \quad 17.2$

$1=$ male

3,449

4,350
Mode of Conviction

Offense Seriousness Score

$0=$ plea

$1=$ trial

4,180

216

4,396

Prior Record Score

4,396

Note: Numbers reflect missing cases and may not equal original sample size $(n=4,396)$. 
Table 2. Frequencies of Dependent and Independent Variables for Pre- and Post-Blakely Samples

\begin{tabular}{|c|c|c|c|c|c|c|}
\hline & \multicolumn{3}{|c|}{ Pre-Blakely } & \multicolumn{3}{|c|}{ Post-Blakely } \\
\hline & $\mathbf{N}$ & $\%$ & Mean & $\mathbf{N}$ & $\%$ & Mean \\
\hline \multicolumn{7}{|l|}{ Dependent Variable } \\
\hline \multicolumn{7}{|l|}{ Upward Departures } \\
\hline No & 1,210 & 44.7 & & 988 & 58.6 & \\
\hline Yes & 1,499 & 55.3 & & 699 & 41.4 & \\
\hline \multicolumn{7}{|l|}{ Independent Variables } \\
\hline \multicolumn{7}{|l|}{ Extralegal Variables } \\
\hline \multicolumn{7}{|l|}{ Race/ethnicity } \\
\hline White & 1,961 & 77.3 & & 1,219 & 77.3 & \\
\hline Black & 340 & 13.4 & & 214 & 13.6 & \\
\hline Hispanic & 117 & 4.6 & & 67 & 4.2 & \\
\hline Other & 120 & 4.7 & & 77 & 4.9 & \\
\hline \multicolumn{7}{|l|}{ Gender } \\
\hline Female & 425 & 16.6 & & 290 & 18.1 & \\
\hline Male & 2,136 & 83.4 & & 1313 & 81.9 & \\
\hline Age & & & 35.8 & & & 33.9 \\
\hline \multicolumn{7}{|l|}{ Mode of Conviction } \\
\hline Plea & 2,536 & 93.6 & & 1,644 & 97.5 & \\
\hline Trial & 173 & 6.4 & & 43 & 2.5 & \\
\hline \multicolumn{7}{|l|}{ Legal Variables } \\
\hline Offense Severity Score & & & 2.84 & & & 2.71 \\
\hline Prior Record Score & & & 2.60 & & & 2.65 \\
\hline
\end{tabular}

Note: Numbers reflect missing cases and may not equal original sample size. 
Table 3. Logistic Regression Results for Baseline, Pre-Blakely, and Post-Blakely Samples

\begin{tabular}{|c|c|c|c|c|c|c|}
\hline & \multicolumn{2}{|c|}{ Baseline } & \multicolumn{2}{|c|}{ Pre-Blakely } & \multicolumn{2}{|c|}{ Post-Blakely } \\
\hline & $\mathrm{b}$ & Odds Ratio & $\mathrm{b}$ & Odds Ratio & $\mathrm{b}$ & Odds Ratio \\
\hline Blakely Timeline & $-0.525^{*}$ & 0.591 & -- & & -- & \\
\hline ("Post-Blakely" = 1) & $(0.066)$ & & & & & \\
\hline \multirow[t]{2}{*}{ Offense Severity Score } & $0.029^{*}$ & 1.030 & 0.026 & 1.026 & 0.038 & 1.039 \\
\hline & $(0.013)$ & & $(0.016)$ & & $(0.021)$ & \\
\hline \multirow[t]{2}{*}{ Prior Record Score } & $0.042^{*}$ & 1.043 & $0.035^{*}$ & 1.036 & $0.056^{*}$ & 1.058 \\
\hline & $(0.012)$ & & $(0.015)$ & & $(0.018)$ & \\
\hline \multirow[t]{2}{*}{ Mode of Conviction } & $0.329^{*}$ & 1.390 & 0.263 & 1.300 & 0.606 & 1.834 \\
\hline & $(0.161)$ & & $(0.183)$ & & $(0.343)$ & \\
\hline \multirow[t]{2}{*}{ Age } & $0.017^{*}$ & 1.018 & $0.020^{*}$ & 1.020 & $0.013^{*}$ & 1.013 \\
\hline & $(0.003)$ & & $(0.004)$ & & $(0.005)$ & \\
\hline \multirow[t]{2}{*}{ Gender } & $0.661^{*}$ & 1.936 & $0.712^{*}$ & 2.038 & $0.573^{*}$ & 1.774 \\
\hline & $(0.087)$ & & $(0.110)$ & & $(0.142)$ & \\
\hline \multirow[t]{2}{*}{ Black } & -0.142 & 0.867 & -0.165 & 0.848 & -0.098 & 0.907 \\
\hline & $(0.095)$ & & $(0.121)$ & & $(0.153)$ & \\
\hline \multirow[t]{2}{*}{ Hispanic } & 0.058 & 1.059 & 0.255 & 1.290 & -0.298 & 0.743 \\
\hline & $(0.156)$ & & $(0.201)$ & & $(0.265)$ & \\
\hline \multirow[t]{2}{*}{ Other } & $-0.397^{*}$ & 0.672 & -0.255 & 0.775 & $-0.660^{*}$ & 0.517 \\
\hline & $(0.154)$ & & $(0.193)$ & & $(0.266)$ & \\
\hline Constant & -1.099 & & -1.205 & & -1.446 & \\
\hline Nagelkerke $\mathrm{R}^{2}$ & 0.068 & & 0.047 & & 0.046 & \\
\hline $\mathrm{N}$ & 4,396 & & 2,709 & & 1,687 & \\
\hline
\end{tabular}

Standard errors in parentheses $* \mathrm{p}<.05$ 
Table 4. Differences in Slopes Test for Independent Samples

\begin{tabular}{lccccc}
\hline & \multicolumn{4}{l}{ Pre-Blakely Sample } & \multicolumn{2}{c}{ Post-Blakely Sample } \\
\hline & b & SE & b & SE & Z score \\
Prior Record Score & 0.035 & 0.015 & 0.056 & 0.018 & 0.896 \\
Age & 0.020 & 0.004 & 0.013 & 0.005 & -1.093 \\
Gender & 0.712 & 0.110 & 0.573 & 0.142 & -0.774 \\
Other Race & -0.225 & 0.193 & -0.660 & 0.266 & -1.324 \\
\hline
\end{tabular}

$* \mathrm{p}<.05$ (two tailed) 